\title{
The Influence of Schedule Salat Towards the Students' Discipline of Doing Salat of SMP 4 Student in Pandemic Time
}

\author{
Sunarmi $^{1 *}$ \\ ${ }^{1}$ Sekolah Menengah Pertama Negeri 4 Samarinda, Indonesia \\ *Corresponding author. Email: sunarmi.yarah@yahoo.com
}

\begin{abstract}
In this pandemic time, all students study from home. All things dealing with academic and nonacademic tasks are managed by the student. This study aimed to know the students' discipline of doing salat by giving schedule salat sent to them each week. This is a survey qualitative study. The data collection of the study was taken from the students' form report, questioner, and interviews with some students using purposive sampling. The data were analyzed using a tally sheet and coding. The subjects of the study were students of SMP 4 Samarinda. The data showed that there is no significant improving frequency of salat from the first week to the tenth week with the schedule salat given. Students who are discipline and indiscipline in doing salat are surrounded by family who has different understanding religion knowledge, and guidance pattern of the family.
\end{abstract}

Keywords: Salat, Schedule salat, Discipline

\section{INTRODUCTION}

Salat is a physical and mental worship activity in Islam. It is an obligation dropped for its converter. Salat means prayer. (Ibadurrahman, 2010) states that salat is worship cover praying, and certain activity (standing bowing) begun with Takbir and end with salam. The obligation of salat found in Quran, surah Al Baqarah 43;

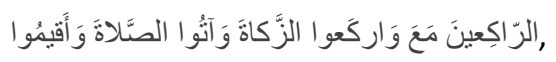

which means Establish prayer, pay alms-tax, 1 and bow down with those who bow down. Salat is conducted in a certain time, movement, prayer reading, a holy and clean condition through wudhu. Salat is compulsory for Muslims to be done. Though the instruction is stated and strict, many students still lazy in doing salat. So, this often comes into a problem that commonly appears among students It needs a lot of effort to make them doing salat, both by the teacher or parents. Any exertions are conducted to manage and lead children or students doing salat, from the tenderly way by modeling until the bit hard way such as punishment. As the study conducted by (Yunus, 2012) found that enhancing salat worship using salat card is effective. While (M. Thohir,
2016) stated that to enhance the salat discipline, it needs some effort and specific tasks scheduled, and Qoran daily recitative deposit towards students result 80 percent parent were satisfied with the improvement students' public salat. Teachers play the roles of educator, mentor, and model in improving students' habituation congregation salat (Purwaningsih, 2017).

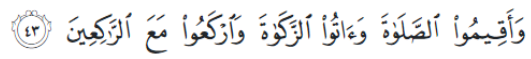

which means Establish prayer, pay alms-tax, 1 and bow down with those who bow down. Salat is conducted in a certain time, movement, prayer reading, a holy and clean condition through wudhu. Salat is compulsory for Muslims to be done.

Though the instruction is stated and strict, many students still lazy in doing salat. So, this often comes into a problem that commonly appears among students. It needs a lot of effort to make them doing salat.

Doing salat is not only became a problem for students but adults either. Although it is not a hard thing, it needs the willingness and sincere to do it. Salat is a hard thing 
for the lazy but it is an easy and simple thing for the humble. As in (Al Qur'an, n.d.) [Al-Baqarah 45];

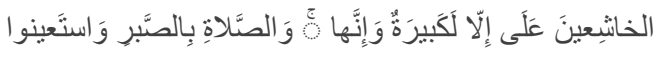

means 'And seek help through patience and prayer. Indeed, it is a burden except for the humble.' This verse implied that salat is very recommended to everyone that needs patient and intended as it is not easy except the humble ones. Students' salat needs continuous monitoring and supervising either directly or indirectly from parent or teacher. (Annisa, 2019) applies students' character building by using salat discipline at school and monitoring the discipline behavior of students at home through a logbook that involves parents and school committee.

\section{LITERATURE REVIEW}

\subsection{Schedule Salat}

Schedule salat is schedule time for doing salat in certain time five times daily that refers to Quran surah Hud 114

$$
\begin{aligned}
& \text { يُذهِبنَ الحَسَناتِ إِنَّ اللَّيلِلِ مِنَ وَزَلَفًا النَّهارِ طَرَفَيِ الصَّلاةَ وَأَقِمِ }
\end{aligned}
$$

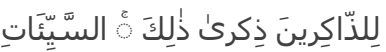

Means, 'and establish prayer at both ends of the day and in the early part of the night. Surely good deeds wipe out evil deeds. That is a reminder for the mindful.'

The schedule salat in one day and one night are Isha, Fajr, Dhuhr, Asher, Magrib, and Isha. The schedule salat has been determined by Religion Ministery. Isha is at 7.30 p.m, Fajr is at 04.30 , Dhuhr is at 12.15 p.m, Asher is at 3.15 p.m and Magrib is at 6.15 p.m. These times would be changed for minutes on a different day either in advance or decline according to the earth rotation and sun position.

\subsection{Discipline}

According to the Oxford dictionary, discipline is a practice of training people to obey rules or a code of behavior. Discipline is important for everyone to developing his character or self-competence to reach achievement. Discipline should be built from habituation to be penetrated the individual. To perform salat it needs not only learning and model but also guidance, habituation, counselling even punishment from adults towards students could even be administered. A study dealing with this was conducted by (Lestari, 2016) which stated that teacher did evaluate salat program and give punishment to enhance salat discipline. The punishment established here should be in form of educated punishment and reward as well. as in (Indarmawan et al., 2014) revealed that the method used in improving worship is habituation, and democratic (educated punishment and reward and motivation for students MDTA Miftahussalam showed consistency in salat, dhikr, and pray).

What has the researchers conducted in the previous study are the ways how to overcome the problem and how to manage and guide the student for doing salat as a foundation stone to build good character.

Character is important for individual and nationbuilding. Character development is the main foundation to develop a nation (Hendarman, 2019). A good character is formed by continuous habituation (Suyanto \& Fitriana, 2020). Similarly, character education is not taught but it is used to (Sudrajat, 2020). Salat is a habituation of character building that is done continuously five times daily at least. The implication of salat is forming discipline, patient, clean, focus, time management, and healthy. It also educates people to be humble, empathetic and avoids violence as all those characteristics exist in salat practice.

Pandemic time forces teachers and students to cut down a chance to build character through salat. No direct instruction, model and habituation, and guidance can help students to grow their character. No teacher knows their movement at home either their salat. This study aimed to know students' discipline of doing salat as a preliminary study. From this study, it is hoped that this research result will give a new perspective for the teacher to take a new policy, certain steps, and treatments in developing students' character through salat for the next study. Technology media is the only tool that can be used between teachers, students, and parents to communicate, deliver tasks and send feedback. The teacher should use the media the most as a bridge to connect with parents. Using the tool media wisely to make the most beneficial in developing character is urgent to be done right now during the pandemic to avoid losing control with students. It is hoped that teachers still able to contribute to educating and developing students' character and competence from distance.

\subsection{Formulated Question}

Stepping from that condition, in this study the researcher intended to apply the schedule salat daily five times to see the students' discipline and the influence of schedule salat toward their salat frequency that is formulated as the following question: (1) how does the students' discipline of salat at home during the pandemic?, (2) is there any influence of schedule salat toward students' salat frequencies? (3), what is the student's response toward salat and their background?

\subsection{The Objective of the Study}


Dealing with the question above, the objective of the study are as follow: (1) to describe the students' discipline in conducting salat, (2), to know whether there is the influence of schedule salat teacher sent toward students' discipline, (3), to know the students' responsibility to schedule salat and their background family.

\subsection{Success Indicator}

Dealing with the question above, the objective of the study are as follow: (1) to describe the students' discipline in conducting salat, (2), to know whether there is the influence of schedule salat teacher sent toward students' discipline, (3), to know the students' responsibility to schedule salat and their background family.

\section{METHODOLOGY}

The subjects of the study are 28 students of SMPN4 Samarinda. The study is conducted for ten weeks from August to October.

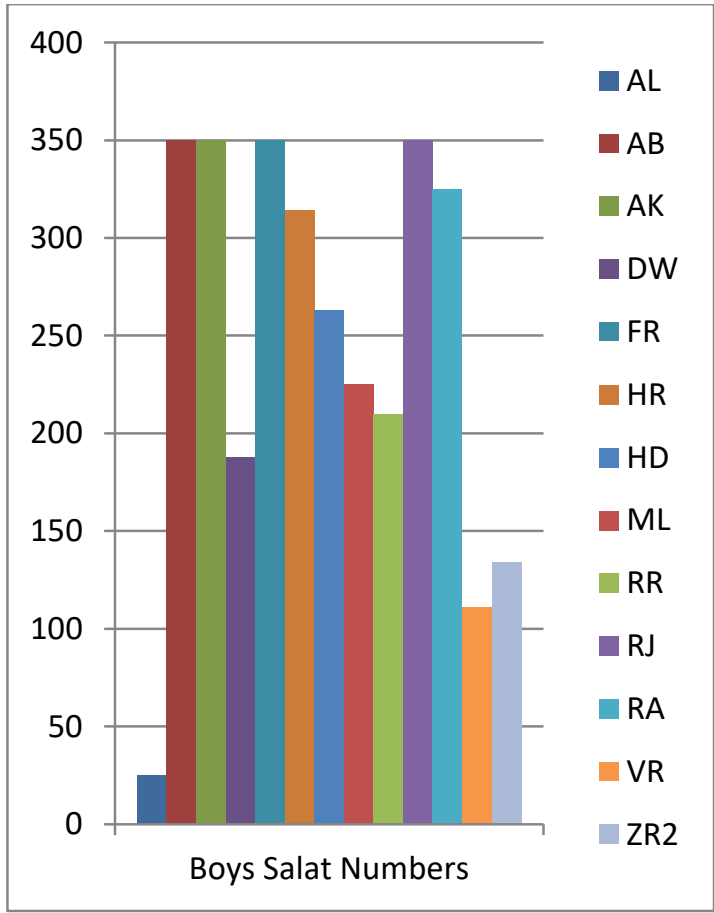

Figure 1 For boy discipline

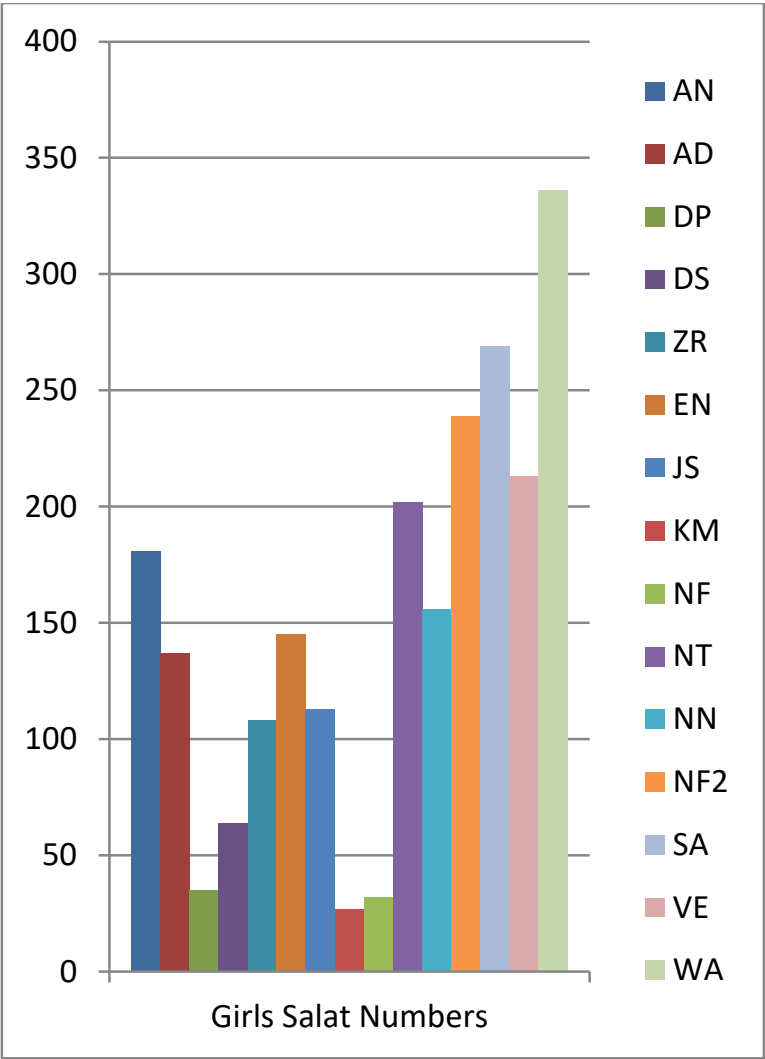

Figure 2 For girl discipline

This is qualitative survey research (Fraenkel \& Wallen, 2009) that intended to know whether students will have discipline in doing salat by the schedule salat given. The schedule salat is made in a form that contains day, date in one number followed with salat time in 5 options. They are fajr, dhuhr, asher, maghrib, and isha.

The student who did salat has to just click the option given and if he doesn't do he can pass them. The form is set unrequired so students can freely fill it or not. Each form contains seven days of the week. So if students do salat neatly all options are filled. The form is sent every the end of the week. The form is applied in Office 365 and put into the link. The link is then sent to students through Whatsapp every the end of the week. To fill this form students are asked to make daily notes for themselves so that they can fill the form according to salat notes (optionally).

The data are from observational and nonobservational (Heigham \& Croker, 2009). Which were taken from the responses of schedule salat the students sent in ten weeks, questioner, and interview using purposive-sampling. The students' form responds in ten weeks then put into excel and tallied to find the maximum total number salat to see the disciplines.

To know influence, the responses are sorted in time order and questionnaire. The interview is conducted by calling through the phone the subjects and parents with open-ended questions to know the background and 
thoughts toward the schedule salat. The interview is done after the two previous data are tabulated. The interview was then transcribed and chunked to see the emerged key point. The excerpts are then put into a table. All the data were put into figures 1,2, and 3 and table To protect the subject's privacy, the researcher put the name into alphabetical order. The subjects have been interviewed in purposive- sampling were those who come into two categories, the very discipline, and the less discipline student.

\section{FINDING AND DISCUSSION}

After ten weeks of observing the student's' 'move', all the responses were then calculated. They started from below 40 until 350 for maximum times salat. The number salat for a boy should reach 350 , and 329 for the girl with the assumption that the girl would have three times free salat because of her monthly menstruation. As menstruation women are banned from doing salat as she is not holy. While salat can only be done for clean and holy Muslims by doing wudhu first. In ten weeks. Even though some girls have only twice monthly menstruation in ten weeks but they will likely have three times as their cycles are different from one another.

In this case, the researcher gives tolerate three-time free salat. The figure above shows that all students do salat with different frequency. 4 students salat below 50 times, 1 below 100, 6 students below 200, for the discipline or fidelity the researcher categorizes students into four: very discipline, discipline, less discipline and lazy. The very discipline students are those who made no absence during the weeks, except because of the monthly menstruation for the girl. The disciplined ones are those who do salat more than 300 with a minimum absence that could be made just one or two in a week and can be tolerated. It can happen because the student was asleep or forgot as they stated in the response. While those who made score below 299 to 200 belong to less discipline as they make absence more than ten percent, it means that they almost do once or twice a day.

Then students that are categorized lazy are those that do salat less than 199 with the assumption they do salat inactive they only do salat when they have mood or remember or when they have any pressure from parents. Finally, those who do salat below 99 are categorized as very lazy as they only do salat once or twice a week. The following is categorizing table.

Table 1 Discipline Table

\begin{tabular}{|l|l|l|}
\hline Number & Category & Students \\
\hline
\end{tabular}

\begin{tabular}{|l|l|l|}
\hline 350 (boy), 329 (girl) & Very Discipline & 5 \\
$300-349$ & Discipline & 2 \\
$200-299$ & Less discipline & 7 \\
$100-199$ & Lazy & 9 \\
$10-99$ & very lazy & 5 \\
\hline
\end{tabular}

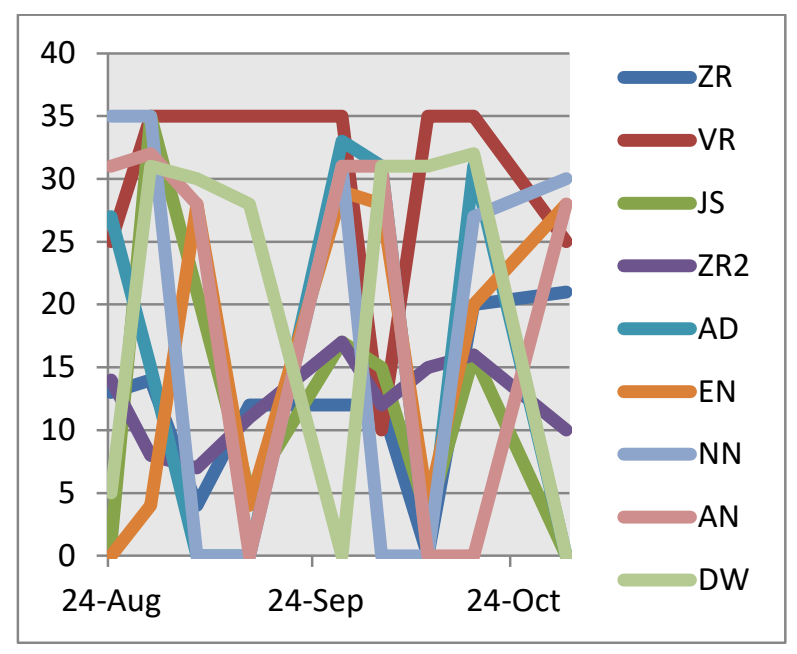

Figure 3 Improving frequency

Apart from the total numbers salat, the researcher also makes the data into a graphic to see the influence of the schedule. To see the influence the researcher sorts the week in an orderly. The numbers of time salat are counted per week from the first week to the tenth week to see whether there will appear any improving frequency of salat times or not. From the graphic in Figure 2, it is seen that two students improve in frequency. However, this occurrence is not significant compared with the number of students in the class. As those are very discipline in the first week make stagnant salat until the last week. This data is also strengthened with the question are given in the questionnaire. They said they aren't influenced at all by the schedule and report they have to make each week. They consistently keep on their track.

\section{Excerpt Interview \\ R: Researcher \\ P: Parent \\ Z; Student \\ $\mathrm{N}$ : Student}

\section{Parent 1}

$R:$ Does your child salat every day?

$P$ : er, yes, she...she doesn't salat when she has a task, ....yes

$R:$ Why your child doesn't salat?

$P$ : er, ......she (no answer)

$R$ : Do you know that it is an obligation?

$P:$ er, ..... (no answer)

Parent 2

$R$ : Does your child salat every day?

P: Yes he is. We always salat together at home. 
$P$; we always go to the mosque, but since the pandemic, we just do it at home, together, yes...

Parent 2

$R:$ I could see that your child do salat regularly, doesn't he?

P: Yes, he does.

$R$ : How do you make your child salat Does he also do other salat?

P: I did it since he was childhood. I said to him, 'you wouldn't pass your exam if you don't salat, etc,'. he ...he (laughing). Yes, I always wake him in the night to do tahajjud. We always do salat together

Student 1

$R$ : Do you salat every day

Z; No

$R:$ Is your parent salat?

Z: er...no

$R:$ Why?

Z: She is always busy working. She sews,

Student 2

$R$ : Do you salat every day?

$\mathrm{N}$ : Yes, I do mam

$R$ : Since when do you perform salat without a hole?

$N$ : Since I was 1st grader

The interview conducted with students in the very discipline and very lazy students are found that the very discipline students come from the family with a good understanding of the religion and strict in obeying religious rules, so the children are aware of the compulsory. They also welcome to teacher's program on the children and have a positive view on it. Those who are lazy and very lazy come from the parent who has a low understanding of religion, unstable emotion, communication and improper relation with children or other people and never do salat, too. They learned to don't care about their children compulsory.

\section{CONCLUSION AND SUGGESTION}

\subsection{Conclusion}

After conducting the research, calculating and discussing the finding, the researcher then come to a conclusion

The very discipline students are low, far less from less discipline, and the lazy and very lazy ones

There is no influence of schedule salat towards students' salat frequency from week one to the tenth. They have stagnant flow and not improve on salat frequencies

Students' responses are good, some say like with the schedule while others say no problem.

\subsection{Suggestion}

This study is conducted without any interruption in the journey. The researcher only asked them to fill the link without any pressure, motivation, or evaluation gradually. This research should be very useful in guiding and motivating students in doing salat five times daily. By giving the schedule students should have hesitated for not doing the compulsory. To enhance students' motivation the teacher should enclose some motivation or evaluation to control before the end of the program for the next study. This result could be used to value them in religion subject instead of doing religion tasks given every week.

\subsection{Recommendation}

It is hoped that this method can enhance the students' understanding and implementing the religious norms and finally it obviously can improve students' character even though the teacher does not exist in front of them every day. For the next study, this method will be beneficial as a remote control to students in this pandemic time. The teacher also can make the most of the parents as a partner in educating students and parents as well indirectly. He can make parents knowing their children compulsory and put their sign in the form before reported. Through this method, the teacher will educate not only students but also the parents indirectly as he/she will shy with the report of the children under his/her control. This will lessen student's laziness and apathetic attitude during the study from home.

\section{ACKNOWLEDGMENTS}

Thank you for

1. The Principal of SMPN 4 Samarinda, Hj. Hadijah S.Pd for her allowing to make this research

2. Mr. Sanudin. S.Ag, the religion teacher for his ideas of discipline table and support to do this research.

\section{REFERENCES}

[1] Al Qur'an. (n.d.).

[2] Annisa, F. (2019). Penanaman Nilai-Nilai Pendidikan Karakter Disiplin pada Siswa Sekolah Dasar. Perspektif Pendidikan Dan Keguruan, 10(1).

[3] Fraenkel, J. R., \& Wallen, N. E. (2009). How to Design and Evaluate Research in Education. McGraw-Hill.

[4] Heigham, J., \& Croker, R. A. (2009). Qualitative Research in Applied Linguistics. Palgrave Macmillan.

[5] Hendarman. (2019). Pendidikan Karakter Era Milenial.

[6] Ibadurrahman. (2010). Pedoman Shalat Lengkap. AMC Press.

[7] Indarmawan, A., Abdussalam, A., \& Wibisana, W. (2014). Upaya Peningkatan Disiplin Ibadah bagi Murid Madrasah. Tarbawy, l(1). 
[8] Lestari, A. B. (2016). Usaha Guru Pendidikan Agama Islam Dalam Menanamkan Kebiasaan Sholat Berjam'ah Siswa SMA Negei 1 Curup Timur Kabupaten Rejang Lebong Provinsi Bengkulu. IAIN Curup.

[9] M. Thohir. (2016). UPAYA PENINGKATAN DISIPLIN IBADAH MELALUI PEMBIASAAN SALAT JAMAAH DI MASJID PADA SISWA DI SDIT DARUL-FIKRI KECAMATAN ARGAMAKMUR KABUPATEN BENGKULU UTARA. Al-Bahtsu, l(2), 239.

[10] Purwaningsih, R. (2017). Peran Guru dalam Pembiasaan Sholat Berjamaah. LITERASI, VIII No.1(1-10).

[11] Sudrajat. (2020). Pendidikan Karakter dalam Keluarga di Masa Pandemi Covid-19.

[12] Suyanto, \& Fitriana, N. (2020). Penguatan Pendidikan Karakter di Era New Normal.

[13] Yunus, M. (2012). Efektivitas Kartu Sholat dalam Meningkatkan Ibadah Sholat pada Peserta Didik MAN Godean Sleman Yogyakarta. UIN Sunan Kalijaga Yogyakarta. 